\title{
Changes of biological properties and pathogenesis of CAEV chimeras expressing Nef and Vpx/Vpr accessory proteins in infected goats

\author{
Yuhai Jin ${ }^{1}$, Géraldine Arrode-Brusés, Naomi Halloway, Opendra Narayan ${ }^{1}$ \\ and Yahia Chebloune*1,2
}

\author{
Address: ${ }^{1}$ University of Kansas Medical Center, Department of Microbiology, Molecular genetics and Immunology, USA and ${ }^{2}$ INRA, Department \\ of Animal health, France \\ * Corresponding author
}

from Frontiers of Retrovirology: Complex retroviruses, retroelements and their hosts

Montpellier, France. 21-23 September 2009

Published: 24 September 2009

Retrovirology 2009, 6(Suppl 2):P22 doi:I0.1186/1742-4690-6-S2-P22

This abstract is available from: http://www.retrovirology.com/content/6/S2/P22

(C) 2009 jin et al; licensee BioMed Central Ltd.

\section{Background}

Caprine Arthritis Encephalitis Virus (CAEV) is a goat lentivirus closely related to HIV that is naturally attenuated with only a minor proportion of infected goats that develop inflammatory diseases, in absence of progression in AIDS. In contrast, to HIV CAEV does not infect productively the CD4+ T cells and has a simpler genome organization. Indeed, CAEV lacks 3 out of 6 regulatory/accessory genes found in HIV. We thought that CAEV/goat is an excellent model to study the functions and the implication of primate lentiviral accessory proteins in the biology and the pathogenesis of lentiviruses.

\section{Materials and methods}

We generated CAEV chimeras by inserting nef or $v p x / v p r$ or both coding sequences in the genome of CAEV [1,2]. All chimeras replicated productively and expressed their transgenes in infected target cells. Interestingly, all 3 chimeras showed increased cytopathicity in target cells, while no modification of the virus titer was observed. We used the chimeric virus that expresses both Nef and Vpx/Vpr in parallel with the parental CAEV to conduct experimental infection of newborn kids and to examine them for 6 months.

\section{Results}

Interstingly, animals infected with the chimeric virus exibited a more persistent viral replication in peripheral blood cells than those infected with CAEV. Longitudinal counts of white blood cells combined with phenotypic examinations of these cells showed persistent decrease in the proportion of circulating $T$ cells in the chimera-infected goats compared with those infected with CAEV. Examination of viral dissemination in tissues of sacrificed animals at 6 months PI showed no difference in target tissues except that virus was isolated CNS of goats infected with the chimera but not with CAEV. Interestingly, all animals infected with the chimera but none with CAEV developed typical interstitial pneumonia in their lungs. In addition we found increased expression of MCP-1 and IP-10 chemoattractant chemokines in the inflamed lungs of chimeracompared with CAEV-infected animals.

\section{Conclusion}

Altogether these data clearly associate the addition/insertion of nef and $v p x / v p r$ transgenes in CAEV genome, with increased virulence of the virus.

\section{Acknowledgements}

This work was supported by the NIH Cobre, K-IMBRE grants and by INRA animal Health Department.

\section{References}

I. Bouzar AB, Villet S, Morin T, Rea A, Genestier L, Guiguen F, Garnier C, Mornex JF, Narayan O, Chebloune Y: Simian immunodeficiency virus $\mathrm{Vpr} / \mathrm{Vpx}$ proteins kill bystander noninfected 
CD4+ T-lymphocytes by induction of apoptosis. Virology 2004, 326:47-56.

2. Bouzar BA, Rea A, Hoc-Villet S, Garnier C, Guiguen F, Jin Y, Narayan $\mathrm{O}$, Chebloune $\mathrm{Y}$ : Activation/proliferation and apoptosis of bystander goat lymphocytes induced by a macrophagetropic chimeric caprine arthritis encephalitis virus expressing SIV Nef. Virology 2007, 364:269-280.

Publish with Bio Med Central and every scientist can read your work free of charge

"BioMed Central will be the most significant development for disseminating the results of biomedical research in our lifetime. " Sir Paul Nurse, Cancer Research UK

Your research papers will be:

- available free of charge to the entire biomedical community

- peer reviewed and published immediately upon acceptance

- cited in PubMed and archived on PubMed Central

- yours - you keep the copyright

Submit your manuscript here:

http://www.biomedcentral.com/info/publishing_adv.asp 